\title{
Islamic relationship value, adaptive selling, and, relationship quality effect to salesforce performance
}

\author{
Jasanta Peranginangin \\ Amie Kusumawardhani \\ Diponegoro University, Indonesia
}

\section{Keywords}

Islamic relationship value, relationship quality, adaptive selling, salesforce performance.

\begin{abstract}
In order to develop a relationship, Islam has several values that must be obeyed by its believers. Indonesia as a country with the largest Moslem population in the world must aware the relational values based on Islamic teachings. In this research, there are four variables used Islamic Relationship Value, Relationship Quality, Adaptive Selling, and Salesforce Performance. Six hypotheses are built in this research to show that the Islamic relationship value has significant impact to Adaptive Selling, Islamic Relationship Value has significant impact to Relationship Quality, the Islamic relationship value has significant impact to salesforce performance, the relationship quality has significant impact to salesforce performance, and the adaptive selling does not have significant impact to salesforce performance. The analytical tools in this research employ Stuctured Eqution Modelling by using SPSS 22 and AMOS 22 software. There are 250 salesforces who are observed by using purposive sampling. The result in this research will give an innovation to marketing studies. The novelty of this research explains the Islamic Relationship Value as a new wave in marketing studies.
\end{abstract}

Corresponding author: Jasanta Peranginangin

Email addresses for corresponding author: jasanta.pa@gmail.com

First submission received: $24^{\text {th }}$ October 2017

Revised submission received: $9^{\text {th }}$ January 2018

Accepted: $6^{\text {th }}$ February 2018

\section{Introduction}

Indonesia is a country with the largest Moslem population in the world. The statistics in 2016 showed that the amount of Moslem in Indonesia reach 207 million inhabitants, Statistics. (2017). Those also identify that Islamic values have great influence to Indonesian's behavior and life. The Islamic values cover all aspects in life included in the product and business relation based on Islamic values.

The products in Islam are bounded by the rule of 'halal' standard. Every product that is produced must be qualified from the standard of 'halal' which is stated by Indonesia certificate board of halal established by Majelis Ulama Indonesia (MUI). The halal label of a product comprises halal of ingredient, halal of production process, halal of packaging, and halal of selling process, Wilson (2012). Halal products are supervised by Majelis Ulama Indonesia (MUI), the violation about halal certificate is a violation that has consequences as criminal law and civil law.

Business relationship is also made through Islamic values that are followed by majority of Indonesian. In order to build long term relationship, it needs to pay attention and apply the Islamic relationship value so that the relationship can be long lasting relationship. Widana et al (2015). The established relationship by salesforce and customer through Islamic relationship value will be widely accepted by Indonesian. The implementation of Islamic Relationship value becomes an obligation that must be applied in establishing the business relationship in Indonesia especially between salesforce and customer. 


\section{Literature Review}

\subsection{Salesforce Performance}

Salesforce performance is a key success to make long lasting sustainable of a company's life. That is why, salesforce is always demanded to improve its performance. Salesforce performance can be measured through two measurements financial performance and non- financial performance, Jeramillo et al (2007). The financial aspects of sales performance are the increasing of selling volume, the profit of each selling unit, the increasing number of customer and the market share. Whereas non-financial performance includes loyalty aspect, discipline, cooperation, and creativity.

Salesforce performance is strongly influenced by the values that lead someone life, the ability to build a quality in relationship, and adaptive selling that someone can do, Velenzuela et al (2014). To increase the sales performance, it is strongly influenced by the tools automation which someone had or someone's excellent intelligence, Mariadoss et al (2014). At last, the increasing of sales performance becomes very important with the carrying capacity of sales performance capability itself and organization supporting capacity, Peranginangin (2016).

\subsection{Islamic Relationship Value}

To build the relation between salesforce and customers, it is inseparable from spiritual dimension, in this case a relation that is built by Islamic values, Alom and Haque (2011). Nguyen and Nguyen (2014) explained that high relationship quality becomes competitive advantage for company; the quality relationship is influenced by the cultural approach that is done by the customer. The built relation through Islamic value requires getting the agreement from both sides. In the Islamic relation value to get the customer, maintain the number of customer, and build the relation in long term periods must be based on Sharia, Enyinda (2014).

The dimension of Islamic relation value that based on holly Qur'an and Sunnah are through giving truthful information (Mushadiq, Surah 2-101), trusted information (Amin, Surah 26-107), giving the best solution (Muqtashid, Surah 35-32), capable to be a mediator (Hakim, Surah 12-52). The Islamic Relation value does not contradict with the common relational value. This relational value can influence the enhancement of sales performance and the quality of relationship significantly, Ulaga and Eggert (2006). According to the researcher's experience, the application of Islamic relationship value also influences toward adaptive selling. Next, we can make several hypotheses as mentioned below:

H1: The higher level of Islamic relationship value then the higher the Adaptive selling.

$\mathrm{H} 2$ : The higher level of Islamic relationship value then the higher the Sales performance.

H3: The higher level of Islamic relationship value then the higher the Relationship Quality.

\subsection{Adaptive Selling}

Adaptive Selling is a capability to do adaptation toward the changing of sales situation. Effectiveness of salesforce strongly depends on someone capability to do adaptive selling. The enhancement of sales performance is aligned with the practice of adaptive selling itself, Weitz et al (1986), and Booth (2007). Adaptive selling is very effective nowadays in which high competitive situation happens, information is easy to obtain, and customer has various character and needs, Kara at al. (2013)

Adaptive selling has dimension to be able to do various approaches, have flexible approach to the customer, understand the customer more, and if one the approach cannot be applied, then change with the new technique approach, Siminitiras et al. (2013). The effectiveness implementation of adaptive selling will give positive influence towards the quality of relationship that was built by the customers, Sing and Das (2013). Next, Pyun (2017) concludes that adaptive selling has greatly impact toward the increasing of quality relation between salesforce and customer. So, we can make hypotheses as below:

H4: The higher level of Adaptive selling then the higher the Relationship Quality.

H5: The higher level of Adaptive Selling then the higher the Salesforce performance.

\subsection{Relationship quality}

Relationship quality is reflected through credibility, commitment, dependency, and satisfaction, Rajaobelina and Bergeron (2009). Relation quality is built through three categories of quality, they are 
partnership quality, service quality, and delivery quality, Palvia et al (2010). Then, the category of quality relation must be strengthened with good after - sale quality.

Relationship quality has strong impact toward customers desire to repeat their purchase and increase their purchasing of product, Moharam and Shawky, (2012) Lai et al. (2013) concludes that relationship quality strongly affects the customers' satisfaction and customer loyalty. Here, a hypothesis can be created as below:

H6: The higher level of Relationship quality then the higher level of salesforce performance.

\section{Research method}

\subsection{Unit analysis}

The unit analysis of this research is the salesforce in Indonesia is taken from the representation of west, central and east region. There are 250 salesforce that was analyzed in which consists of $45 \%$ male and $55 \%$ female. The age range of respondents is between 20 years to 45 years old, according to the data, it is known that the married respondents are $63,2 \%$ and single respondents are $37,8 \%$. The Last education of respondents is senior high and bachelor degree, whereas the amount of team work is between 2 to 10 people. The number of respondent has fulfilled the qualification as required in structural equation modeling, Ferdinand (2012) and hair et al. (2014).

\subsection{Analytic Technique}

The sampling method in this research used Purposive sampling method in which the respondents become the analysis unit based on the predefined criteria, Zikmund et al. (2012). The analysis technique used Structural Equation Modeling (SEM) with SPSS 22 and AMOS 22 software. The reliability in this research is measured by using construct reliability with cut off value $\geq 0,70$ Fornel and Larcker (1981) and convergent validity with cut off value $\geq 0,70$, Tabachnick and Fidell (2013).

\section{Result}

\subsection{Validity and reliability}

The result of data processes shows that all indicators from the observed variable have their loading factor to cut off value $\geq 0,60$ which it means that all indicators from variable are well observed. The convergent calculation and construct reliability are shown on the table below:

\begin{tabular}{|c|c|c|c|}
\hline Variable \& Inicator & Standard Loading & $\begin{array}{l}\text { Convergent Validity (AVE) } \\
\geq 0.50\end{array}$ & $\begin{array}{ll}\text { Construct } & \text { Reliability } \\
0.70 & \end{array}$ \\
\hline \multicolumn{4}{|c|}{ Relationship Quality } \\
\hline RQ1 & 0.751 & \multirow{3}{*}{0.691} & 0.870 \\
\hline RQ2 & 0.825 & & \\
\hline RQ3 & 0.91 & & \\
\hline \multicolumn{4}{|c|}{ Salesforce Performance } \\
\hline SP1 & 0.701 & \multirow{3}{*}{0.518} & 0.763 \\
\hline SP2 & 0.742 & & \\
\hline SP3 & 0.716 & & \\
\hline \multicolumn{4}{|l|}{ Adaptive Selling } \\
\hline AS1 & 0.69 & \multirow{3}{*}{0.514} & 0.760 \\
\hline AS2 & 0.749 & & \\
\hline AS3 & 0.71 & & \\
\hline \multicolumn{4}{|c|}{ Islamic Reationship Value } \\
\hline IRV1 & 0.709 & \multirow{3}{*}{0.544} & 0.781 \\
\hline IRV2 & 0.796 & & \\
\hline IRV2 & 0.703 & & \\
\hline
\end{tabular}

Tabel 1: Convergent Validity and Construct Reliability 
On the table above, it shows that the use of cut off value $\geq 0,50$ for convergent validity, the variable of relationship quality value is 0,691 , the variable of salesforce performance is 0,518 , the variable of adaptive selling is 0,760 , and the variable of Islamic relationship value is 0,781 . The cut off value for construct reliability is $\geq 0,70$, it can be concluded that all variables in this research are very reliable.

\subsection{Goodness of Fit Index}

In this research, structural equation model uses software AMOS that requires availability the goodness of fit index. The result is presented on the table below:

\begin{tabular}{llll}
\hline Goodness of Fit Index & Cut Off Value & Result & Explanation \\
\hline Chi-Square & Ecpected small & 90,801 & Fit \\
\hline Significancy prob & $\leq 2$ & 1,713 & Fit \\
\hline Sig. & $\leq 0,05$ & 0,001 & Fit \\
\hline GFI & $\geq 0,90$ & 0,931 & Fit \\
\hline AGFI & $\geq 0,90$ & 0,898 & Fit \\
\hline TLI & $\geq 0,95$ & 0,959 & Fit \\
\hline CFI & $\geq 0,95$ & 0,967 & Fit \\
\hline RMSEA & $0,03-0,08$ & 0,059 & Fit \\
\hline
\end{tabular}

Table 2: Goodness of Fit Index

From the table above, it is obtained the chi-square value 90,801 , the significance probability value with cut-off $\leq 2$ was obtained result 1,713, the significance value with cut off $\leq 0,5$ was obtained 0.001 , the goodness of fit index (GFI) value with cut off value $\geq 0,90$ was obtained result 0,931 , the adjusted goodness of fit index (AGFI) values with cut off value $\geq 0,90$ was obtained result 0,898 , the tucker lewis index (TLI) value with cut off value $\geq 0,95$ was obtained result 0,959 , the root mean square error of approximant (RMSEA) value with cut off vale 0,03-0,08 was obtained result 0,059 . Based on the result of data processing above, the built model has well the good of fit index.

\subsection{Result of Hypothesis Testing}

The result of data testing hypothesis is a Statistical Regression Weight, it is obtained the number and presented below:

\begin{tabular}{llllllll}
\hline Hypothesis & & $\begin{array}{l}\text { Estim } \\
\text { ate }\end{array}$ & S.E & C.R & P & Sig \\
\hline H1 & Islamic Relationship Value & $\rightarrow$ Adaptive Selling & .711 & .102 & 6.995 & $* * *$ & Sig. \\
\hline H2 & Islamic Relationship Value & $\rightarrow$ Salesforce Performance & .317 & .117 & 2.702 & .007 & Sig. \\
\hline H3 & Islamic Relationship Value & $\rightarrow$ Relationship Quality & .362 & .107 & 3.371 & $* * *$ & Sig. \\
\hline H4 & Adaptive Selling & $\rightarrow$ Relationship Quality & .748 & .097 & 7.729 & $* * *$ & Sig \\
\hline H5 & Adaptive Selling & $\rightarrow$ Salesforce Performance & .309 & .193 & 1.604 & .109 & Not Sig. \\
\hline H6 & Relationship Quality & $\rightarrow$ Salesforce Performance & .430 & .213 & 2.025 & .043 & Sig. \\
\hline
\end{tabular}

Significant at $\leq 0,05$

Tabel 3 : Testing Results of Statistical Regression Weight

The result of data processing toward the hypothesis is obtained based on P value in which the Islamic relationship value toward adaptive selling is very significant, further the influence of Islamic relationship value to relationship quality is very significant, as well as the influence of adaptive selling towards relationship quality is very significant. The influence of Islamic relationship value towards salesforce performance is at 0,007 , whereas the influence of relationship quality toward salesforce performance is significant at 0,043 , and last the influence of adaptive selling towards salesforce performance is positive but it is not significant.

On the figure 1 below is presented the complete figure of this research: 


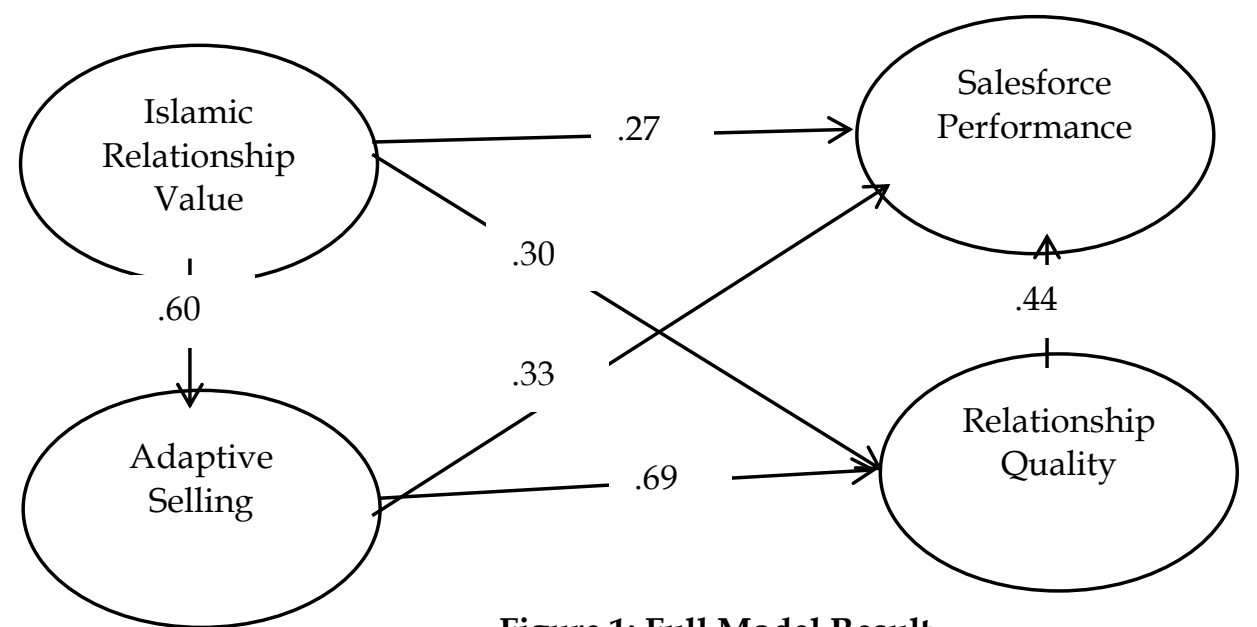

Figure 1: Full Model Result

\section{Conclusion and Discussions}

This research presents the conceptual framework and empirical by testing the relation between variable. The result of hypothesis testing shows that three hypotheses are proved very significant, two significant hypotheses, and one hypothesis is positive but not significant. The findings of this research prove that salesforce performance is directly influenced by Islamic relationship value and it can be strengthened through mediation of relationship quality.

From this research, it is found that salesforce performance depends on the values of salesforce itself. Islamic relationship value becomes the solution toward the salesforce's success that gives managerial implication to improve those values gradually through formal workshop or additional material in every interaction with salesforce.

In order to accomplish a perfect research of this result, it is needed further researches. The future topic can add other variables in the research model. Furthermore, the research can be conducted by adding the number of respondent's population in order to represent the real condition of salesforce management, and the last the continuing research also needs the object research from other country.

\section{References}

Alom, M. M. \& Haque, M. S. 2011. Marketing: An Islamic Perspective. World Journal of Social Sciences, Vol. 1. No. 3, Pp. 71-81.

Booth, B. D. 2007. The relationship between buyer orientations and the influence tactics used by salespersons in adaptive selling - a replication with extension study. Master of Business Administration, University of Pretoria.

Enyinda, C. I. 2014. Evaluation of Relationship Marketing in Islamic Banks in The UAE: Empirical Evidence Based On Sensitivity Analysis Algorithm. Journal of Economic \& Financial Studies, Vol. 02, No. 03, pp. 01-12.

Ferdinand, A. T. 2012. Management Research Methode - Metode Penelitian Manajemen, Semarang, Indonesia, Undip Press.

Fornell, C. \& Larcker, D. 1981. Evaluating structural equation models with unobsevable variables and measurement error. Journal of Marketing Research, 18, 39-50.

Hair, J. F., Black, W. C., Babin, B. J. \& Anderson, R. E. 2014. Multivariate Data Analysis, United State of America, Pearson Education Limited.

Jaramillo, F., Ladik, D. M., Marshall, G. W. \& Mulki, J. P. 2007. A Meta Analysis of The Relationship Between Sales Orientation-Customer Orientation (SOCO) and Salesperson Job Performance. Journal of Business \& Industrial Marketing, Volume $22 \cdot$ Number 5.

Kara, A., Andaleeb, S. S., Turan, M. \& Cabuk, S. 2013. An examination of the effects of adaptive selling behavior and customer orientation on performance of pharmaceutical salespeople in an emerging market. Journal of Medical Marketing: Device, Diagnostic and Pharmaceutical Marketing 2013 13: 102, 13, 102-114.

Lai, M.-C., Chou, F.-S. \& Cheung, Y.-J. 2013. Investigating Relational Selling Behaviors,Relationship Quality, and Customer Loyalty in the Medical Device Industry in Taiwan. International Journal of Business and Information, 8, 137-149.

Mariadoss, B. J., Milewicz, C., Lee, S. \& Sahaym, A. 2014. Salesperson competitive intelligence and performance: The role of product knowledge and sales force automation usage. Industrial Marketing Management, 43, 136-145. 
Moharam, O. M. \& Shawky, A. Y. 2012. Measuring The Effects of Personalized Integrated Marketing Communication Tools on the Consumers" Intention to Purchase Credit Cards in the Private Banking Sector in Egypt. American Academic \& Scholarly Research Journal, 4, 1-14.

Nguyen, T. T. M. \& Nguyen, T. D. 2014. The impact of cultural sensitivity and information exchange on relationship quality. Marketing Intelligence \& Planning, 32, 754 - 768.

Palvia, P. C., King, R. C., Xia, W. \& Palvia, S. C. J. 2010. Capability, Quality and Performance of Offshore IS Vendors: A Theoretical Framework and Empirical Investigation. Decision Sciences, 41.

Peranginangin, J. 2016. The Handbook of Sales People : Konsep dan Aplikasi Manajemen Penjualan Sidoarjo, JP Publishing.

Pyun, H. S. 2017. The Relationship Between salesperson's Adaptive Selling Behavior, Rapport, Job Satisfaction, and Organizational Commitment in The Distribution Channel. Indian Journal of Science and Technology, Volume 9.

Rajaobelina, L. \& Bergeron, J. 2009. Antecedents and consequences of buyer-seller relationship quality in the financial services industry. International Journal of Bank Marketing, 27, 359-380.

Simintiras, A. C., Ifie, K., Watkins, A. \& Georgakas, K. 2013. Antecedents of adaptive selling among retail salespeople: A multilevel analysis. Journal of Retailing and Consumer Services, 20, 419-428.

SINGH, R. \& DAS, G. 2013. The impact of job satisfaction, adaptive selling behaviors and customer orientation on salesperson's performance: exploring the moderating role of selling experience Journal of Business $\mathcal{E}$ Industrial Marketing, 28, 554-564.

Statistics. 2017. Social and Population [Online]. Jakarta: Badan Pusat Statistik/Statistics Indonesia. Available: www.bps.go.id.

Tabachnick, B. G. \& Fidell, L. S. 2013. Using Multivariate Statistics, United State of America, Pearson Education.

Ulaga, W. \& Eggert, A. 2006. Relationship Value and Relationship Quality : Broadening and Nomological Network of Business to Business Relationship. European Journal of Marketing, Voume 10, No.3/4, pp. 311-327.

Valenzuela, L., Torres, E., Hidalgo, P. \& Farías, P. 2014. Salesperson CLV orientation's effect on performance. Journal of Business Research, 67, 550-557.

Weitz, B. A., Sujan, H. \& Sujan, M. 1986. Knowledge, Motivation, and Adaptive Behavior: A Frame-work for Improving - Selling Effectiveness. Journal of Marketing, 50, 174-191.

Widana, G. O., Wiryono, S. K., Purwanegara, M. S. \& Toha, M. 2015. Exploring The Impact of Islamic Business Ethics and Relationshi Marketing Orientation On Business Performance: The Islamic Banking Experience Asian Academy of Management Journal, Vol. 20, No. 1, pp. 1-25.

Wilson, J. A. J. 2012. The New Wave of Transformational Islamic Marketing Reflections and Definitions. Journal of Islamic Marketing, Vol. 3 No. 1, pp. 5-11.

Zikmund, W. G., Babin, B. J., Carr, J. C. \& Griffin, M. 2012. Business Research Methode, United State of America, Cengage Learning. 